\title{
KEMESIASAN YESUS BERDASARKAN LUKAS 4:18-19 SEBAGAI DASAR HOLISTIC MINISTRY GEREJA
}

\section{Dina Elisabeth Latumahina}

\section{PENDAHULUAN}

Secara global, masyarakat dunia sedang menghadapi tiga masalah besar yaitu masalah degradasi lingkungan hidup, disintegrasi sosial dan masalah kemiskinan. Yang pertama, masalah degradasi lingkungan hidup. Sumbersumber daya dunia sedang dihabiskan lebih cepat daripada mereka dapat digantikan. Pencemaran lingkungan dan Global Warming menjadi masalah utama dunia saat ini. Yang kedua, masalah disintegrasi sosial yang telah menghancurkan tatanan masyarakat. Masalah perceraian yang sedang booming, bunuh diri, tawuran, pemakaian obat-obat terlarang yang tidak dapat dibendung lagi. Relasi sosial antar masyarakat telah diwarnai dengan diskriminasi, intimidasi, anarkhisme. Yang ketiga, masalah kemiskinan. Pada dewasa ini dunia menghadapi kenyataan bahwa lebih dari satu milyard umat manusia (seperlima penduduk dunia) hidup dalam kemiskinan yang mutlak dan jumlah bilangan ini terus bertambah. Ada kesenjangan sosial yang semakin melebar antara si kaya dan si miskin. Melihat semua masalah di atas, gereja tentunya tidak boleh menutup mata atau melipat tangan dan mengatakan bahwa itu bukan urusan gereja.

\section{A. KEMESIASAN YESUS DALAM PERJANJIAN LAMA}

Mulai zaman Perjanjian Baru sampai sekarang, pengertian tentang Mesias bahwa Dia adalah Yesus Kristus yang telah datang ke dunia untuk menyelamatkan manusia berdosa sehingga memperoleh hidup yang kekal adalah pengertian yang sudah baku. Tetapi sebelum itu, orang-orang Israel zaman Perjanjian Lama sudah memiliki pengharapan mesianis menurut pengertian yang diperoleh dari nubuat-nubuat para Nabi Perjanjian Lama. ${ }^{1}$ Berdasarkan nubuat-nubuat tersebut, dan atas bimbingan Roh Kudus, Yohanes

${ }^{1}$ SM Siahaan, Pengharapan Mesias Dalam Perjanjian Lama, Jakarta: BPK Gunung Mulia, 1991, h.3 
Pembaptis dan para Rasul Perjanjian Baru mengenali Yesus sebagai Mesias yang dijanjikan dalam Perjanjian Lama.

\section{Terminologi}

Kata Mesias diambil dari bahasa Ibrani Meshiah yang berarti 'yang diurapi'. Kata dasarnya 'masah' artinya 'mengurapi'. Bahasa Yunani menyebut 'Kristos', dari kata kerja khrio yang berarti 'mengurapi'. Dalam Perjanjian Lama, jabatan-jabatan resmi yang selalu didahului oleh pengurapan adalah jabatan Raja, Imam dan Nabi. $^{2}$ Minyak yang dituangkan dalam pengurapan tersebut adalah lambang Roh Kudus, seperti yang telah dikatakan dalam Yesaya 61:1; Zakharia 4:1-6, juga sekaligus melambangkan pengubahan satu pribadi sehingga dipenuhi Roh-Nya. Sebagai tanda, ada tiga hal yang dilihat sebagai dampak pengurapan yaitu: 1) pengesahan yang menunjukkan sahnya pekerjaan tersebut sekaligus diberi kemampuan untuk melaksanakannya. 2). Penetapan relasi dengan Allah, ada status bagi yang diurapi sehingga orang lain tidak boleh berbuat sembarangan terhadap 'yang diurapi'. ${ }^{3}$ 3). Komunikasi dengan Allah yang bersifat dinamis fungsional. Sebagai contoh, ketika Roh Tuhan berkuasa atas Daud dan Roh Kudus sebagai meterai yang menjamin orang yang diurapi Tuhan, seperti Mazmur 2:2; Kisah Para Rasul 4:27.

Pada umumnya dalam Perjanjian Lama, pengurapan merupakan penetapan atau pentabisan untuk tugas tertentu, memberi wewenang, wibawa dan kuasa, kekuatan, kemampuan untuk melaksanakan tugas tersebut. ${ }^{4}$ Tindakan pengurapan adalah hak mutlak Allah yang diberikan kepada Raja, Imam dan Nabi dengan tujuan melayani-Nya.

\section{a. Mesias sebagai Raja}

Mesias sebagai Raja berasal dari keturunan Yehuda. Tongkat Kerajaan akan tetap pada Yehuda sampai dituntut oleh penguasa terakhir yaitu Mesias

\footnotetext{
${ }^{2}$ Kel.29:7; Im.4:3; Hak.9:8; I Sam.9:16; 10:1; II Sam.19:10

${ }^{3}$ Band. Dengan I Sam.24:7; 26:9; II Sam.1:14

4 TGR Boeker, Apa Kata Alkitab Tentang Roh Kudus, Batu: I-3, 1991, h.13
} 
sebagai Raja di atas segala raja dan Tuan di atas segala tuan. Dia-lah yang berhak untuk duduk di atas tahta Daud. Dia tidak hanya memerintah Kerajaan Daud tetapi bangsa-bangsa lain akan takluk juga kepada-Nya. Sang Mesias akan diberkati, akan memerintah pada zaman kelimpahan, Dia akan menambatkan keledai-Nya pada pohon anggur, dan anak keledainya pada pohon anggur pilihan; dia akan mencuci pakaiannya dengan anggur dan bajunya dengan darah buah anggur; matanya akan merah karena anggur dan giginya akan putih karena susu. ${ }^{5}$

Mazmur-mazmur berbicara mengenai watak dan tugas Mesias sebagai Raja; Dia akan menghadapi perlawanan dunia, tetapi Dia akan menang. Dia akan memerintah dunia, pemerintahan-Nya kekal, kerajaan damai sejahtera, ketaatan-Nya kepada Yahwe tak tergoyahkan. Dia sahabat orang miskin dan musuh para penindas. Dia pewaris Perjanjian Yahwe dengan Daud, Dia anak Yahwe, duduk di sebelah kanan-Nya dan Dia sendiri Ilahi. ${ }^{6}$

Kitab Yesaya juga banyak menubuatkan mengenai Mesias sebagai Raja. ${ }^{7}$ Yesaya berbicara mengenai Raja Keturunan Daud yang dikaruniai Roh Allah, Kerajaan-Nya adalah Kerajaan Moral dan keadilan, rohani, penuh damai sejahtera Ilahi, meliputi bangsa-bangsa, dan Israel akan dipulihkan.

\section{b. Mesias sebagai Nabi}

Dalam Ulangan 18:15-19, Musa mengatakan bahwa: "Seorang Nabi 'seperti aku' akan dibangkitkan oleh Yahwe". Umumnya para penafsir dan para teolog sepakat bahwa yang dimaksudkan dengan 'seorang nabi seperti aku' itu adalah Mesias yang lebih pantas untuk itu dibandingkan dengan para Nabi yang lain dalam Perjanjian Lama. Musa adalah pengantara Perjanjian Sinai; para Nabi lain adalah pemberita perjanjian ini dan menubuatkan penggantinya. Musa adalah pemula; para nabi lain adalah nabi penyiar. Dengan Musa, agama Israel memasuki masa baru; para nabi berjuang agar masa itu ditegakkan dan tetap ada, dan menyediakan jalan bagi masa yang akan menyusul, yang mereka idam-idamkan. Maka nubuatan tersebut hanya digenapi oleh Mesias.

\footnotetext{
${ }^{5}$ Kejadian 49:9-10

${ }^{6}$ Mazmur 2:1-10;72;110;45;89

${ }^{7}$ Yesaya $7,9,45$
} 


\section{c. Mesias sebagai Imam}

Keimaman Mesias mengikuti peraturan Melkisedek. Dalam Mazmur 110:4, seorang Raja Keturunan Daud ditetapkan dengan sumpah Allah menjadi imam untuk selama-lamanya menurut Melkisedek. Latar belakang penetapan ini terdapat dalam hal penaklukan Yerusalem oleh Daud tahun 1000 BC, dan berdasarkan ini Daud dan keturunannya menjadi ahli waris atas jabatan imamraja dari Melkisedek. Jabatan Imam sangat jelas menjadi bagian dari kekuasaan raja, karena penguasa terhormat Yerusalem sekaligus menjadi imam besar Yerusalem. Jabatan rangkap ini dimulai Daud menurut Mazmur 110, menggantikan Melkisedek. Di dalam dirinya, dia membangun altar untuk Allah dan mempersembahkan korban; dia ingin membangun Bait Allah; dia membawa tabut Perjanjian ke Yerusalem, dengan berpakaian imam.

Salomo juga menjadi imam tertinggi; dia membangun Bait Allah dan menabiskan Bait Allah tersebut, dan mempersembahkan kurban di depan tabut perjanjian sambil berkhotbah dan memberkati bangsa Israel (I Raj.8). Pekerjaan-pekerjaan tersebut sebenarnya tugas Imam Besar. Tetapi Raja adalah imam tertinggi dan bahkan dia mengurapi para imam. ${ }^{8}$

Yesus adalah Raja yang ditetapkan dengan cara demikian, oleh orangorang sezaman-Nya disebut Mesias Anak Daud. Dia harus menjadi imam untuk selama-lamanya menurut peraturan Melkisedek. Ibrani 5:6-11;6:20-7:28 menjelaskan keimaman Yesus di surga berdasarkan Mazmur 110 dengan penjelasan dari Kejadian 14:18 dan berikut. Melkisedek lebih tinggi dari Abram, maka ditetapkan bahwa keimaman Kristus bukan dari keturunan Harun tetapi dari Melkisedek, dan keimaman Kristus lebih tinggi dari keimaman keturunan Lewi dalam Perjanjian Lama. ${ }^{9}$

\section{Problematika Pengharapan Mesianis dalam Perjanjian Lama}

\footnotetext{
${ }^{8}$ II Sam.8:17;20:15;I Raj.2:26

${ }^{9}$ SM Siahaan, Pengharapan Mesias....h.9-10
} 
Beberapa pandangan tentang pengharapan Mesianis orang-orang zaman Perjanjian Lama $:^{10}$

\section{a. Pandangan Literal-Kritis}

Pandangan ini mengatakan bahwa pengharapan mesianis Israel adalah Mesias akan datang untuk mengangkat bangsa yang terhina menjadi bangsa yang dihormati kembali di antara bangsa-bangsa masa itu.

\section{b. Pandangan Historis-Religius}

Pandangan ini berpendapat bahwa Mesias adalah tokoh yang sempurna bagi Israel yang akhirnya memberikan keselamatan tertinggi bagi manusia. Ada latar belakang politis tetapi akhirnya tersembunyi di balik pandangan religious. Selanjutnya, menurut pandangan ini, Mesias hanya satu, yang di dalam diriNya membawa keselamatan bagi Israel dan semua manusia, tetapi dalam perjalanan waktu pengharapan ini semakin kabur. Kemudian masuklah pemikiran-pemikiran eskatologis yang mengakibatkan pindahnya pengharapan mesianis ke waktu dekat, ataupun waktu yang jauh dari pendengar nubuat.

\section{c. Pandangan Konservatif}

Pandangan ini beranggapan bahwa tujuan Yahwe dalam Perjanjian Lama adalah membangun bangsa yang rohani dengan religi dan budaya yang benar, dan dalam kerajaan ini akan berkuasa seorang Penyelamat. Sesuai dengan tugas-Nya, Dia dinamai Pemenang atau Bintang Yakub. Setelah Kerajaan dalam bangsa Israel didirikan sesuai dengan kehendak Allah, dan Raja Daud menduduki tempat yang terhormat, maka muncul pengharapan terhadap Penyelamat dalam bentuk Raja. Jenis pengharapan itu digambarkan berhubungan dengan besarnya bangsa, nama yang masyur, akhir dari perang politik, pemerintahan yang gemilang dan damai.

\section{d. Pandangan dari segi Fungsi Kultus}

Pandangan ini berangkat dari apa yang dijelaskan Kitab Mazmur mengenai Mesias. Pandangan ini memberikan makna kepada posisi raja pada ibadah di

${ }^{10}$ Ibid, 5-8 
Bait Allah untuk meneruskan kekuatan Allah kepada bangsa Israel. Dengan demikian raja adalah jaminan keselamatan. Mulanya menurut pandangan ini pengharapan Mesias masih berpusat pada kebangkitan kembali dinasti Daud tetapi kemudian pengharapan tersebut menuju Mesias yang hidup dan berkuasa kekal.

\section{e. Aliran yang menekankan Ritus-Ritus}

Menurut pandangan ini, manusia pertama Adam adalah pemegang kekuasaan yang diberikan Allah. Dalam sejarah Israel, kekuasaan tersebut dipegang oleh raja yang sekaligus Mesias, yang membawa keselamatan untuk bangsanya. Pada zaman pembangunan, kedudukan ini diduduki oleh 'hamba yang menderita'. Dan dalam Kitab Daniel, manusia pertama ini dinyatakan sebagai 'Anak Manusia'. Ketiga posisi ini yaitu Raja-Mesias, Nabi dan Anak Manusia dapat ditarik kembali pada manusia pertama yang diberi Allah tiga jabatan di atas.

\section{f. Pandangan Historis-Tradisional}

Pandangan ini mengatakan bahwa penobatan Dinasti Daud belum termasuk dalam janji di Gunung Sinai. Janji kekekalan Dinasti Daud tidak menjadi bagian dari sejarah janji keselamatan Allah di masa kuno. Dinasti Daud menjadi bagian dari keselamatan baru.

Dalam II Samuel 7 dikatakan bahwa janji Allah untuk membangun rumah dinasti Daud: janji Allah bahwa Daud akan berkuasa atas Israel dan kekuasaannya kekal; Yahwe akan menjadi Bapa bagi Daud dan keturunannya; Yahwe akan mengikat perjanjian kekal dengan Daud.

\section{g. Pandangan Historis-Kritis}

Pandangan ini mengatakan bahwa istilah Mesias pada awalnya ditujukan kepada keturunan Daud, dan baru pada masa pembuangan dialihkan kepada pengharapan eskatologis, raja kekal di masa datang. Raja itu akan duduk di tahta Daud dan akan memerintah secara adil. Mesias digambarkan sebagai tokoh politis dan eskatologis. 
Kesimpulan: 1). Adanya perbedaan interpretasi terhadap pengharapan Israel karena adanya perbedaan interpretasi terhadap Perjanjian Lama. 2). Adanya perbedaan konsep pengharapan mesianik dan munculnya pengharapan mesianik yang tidak utuh dan seperti yang dimaksudkan Alkitab adalah 'wajar' apalagi penekanannya kepada aspek kekinian, fisik dan politis, karena situasi politis bangsa Israel yang sangat lama menderita di bawah penjajahan bangsabangsa kafir sejak penjajahan Babel, Media-Persia, Yunani dan Romawi.

\section{B. KEMESIASAN YESUS DALAM PERJANJIAN BARU}

\section{Interpretasi Mesias dalam Perjanjian Baru}

Istilah "Mesias" dalam Perjanjian Baru diterjemahkan dengan kata Yunani Kristos yang berarti 'yang diurapi'. Dalam Alkitab terjemahan Bahasa Indonesia, Mesias diterjemahkan dengan kata Kristus tetapi juga Mesias dan 'yang diurapi'. Mesias adalah Yesus dari Nazaret yang pada saat pembaptisan-Nya diurapi dengan Roh Kudus dan kuat kuasa Allah (Kis.10:38). Tetapi Tuhan Yesus sendiri jarang menggunakan istilah Mesias untuk diri-Nya sendiri. Hal ini disebabkan karena adanya kesalah-pahaman yang timbul dari penggunaan istilah itu, baik yang terjadi pada zaman Perjanjian Lama maupun yang dapat terjadi pada zaman Perjanjian Baru, zaman Tuhan Yesus selagi di dunia.

Ketika Petrus menyatakan pengakuannya bahwa 'Engkaulah Mesias, Anak Allah yang hidup', Dia menerimanya, tetapi memerintahkan muridmurid-Nya untuk tidak menceriterakan itu kepada siapa pun. ${ }^{11}$ Dalam percakapan-Nya dengan perempuan Samaria ${ }^{12}$, istilah itu pasti dipahami dalam terang pengharapan perempuan Samaria bahwa akan datang seorang taheb atau 'yang membetulkan', nabi seperti Musa yang dijanjikan dalam Ulangan 18:15-19. Tetapi, ketika Dia ditantang oleh Imam Besar pada saat penghakiman-Nya, supaya Dia mengatakan apakah Dia Mesias, Anak dari

${ }^{11}$ Matius 16:13-16; Markus 8:29-30

12 Yohanes 4:25-26 
Yang Terpuji atau tidak, Dia mengaku, dan kata-kata dari ucapan-Nya dijadikan dakwaan bahwa Dia menghujat Allah. ${ }^{13}$

Sekali lagi Tuhan Yesus tidak pernah memproklamasikan diri-Nya sebagai Mesias, namun Tuhan Yesus juga tidak menolak gelar Mesias bagi diri-Nya. Tetapi pengertian Yesus mengenai kemesiasan-Nya berbeda dengan gambaran umum bangsa Israel tentang Mesias yang mereka harapkan. Dia menolak setiap unsur yang berbau politis dan nasionalisme. Ketika Yesus dibaptis, suara dari surga menyambut Dia sebagai Mesias dari suku Daud dengan memakai kata-kata dari Mazmur 2:7, tetapi juga menambahkan katakata dari Yesaya 52:1 yang memperkenalkan Hamba Yahwe. Ini pertanda bahwa KeMesiasan-Nya akan menggenapi gambaran Hamba yang rendah hati, taat, menderita, menggenapi tugas-Nya melewati maut, sambil menyerahkan pembelaan diri-Nya kepada Allah.

Pelayanan Yesus yang dimahkotai dengan penderitaan inilah yang memberikan arti baru kepada 'mesias' yang jelas berbeda dengan pengertian sebelumnya. Sedangkan pembebasan yang tadinya dilihat sebagai pembebasan bersifat politis, sekarang Yesus melihatnya sebagai pembebasan dari dosa dan penghukuman. Kerajaan-Nya tidak bersifat jasmani melainkan rohani.

Seperti dalam Perjanjian Lama, Mesias atau Kristus adalah Orang yang diurapi yang mempunyai jabatan dan peran sebagai Raja, Imam dan Nabi. Sebagai Raja yang bersifat Rohani, Mesias/Kristus berkuasa mengampuni dosa (Mark.2:10;10:45), menghakimi orang berdosa (Mat.25:31-36). Sebagai Imam, Dia menjadi Imam Besar menurut peraturan Melkisedek, Dia mempersembahkan kurban karena dosa bahkan Dia sendiri adalah kurban yang kekal (Ibr.3:4; 4:14; 5:5; 6:20; 7:26). Dia pendoa syafaat bagi umat-Nya, Dia memberkati umat-Nya atas nama Allah. Dia Tuhan atas Hari Sabat (Luk.6:5).

Sebagai Nabi, telah dinubuatkan dalam Ulangan 18:15 sebagaimana juga tertulis dalam Kisah Para Rasul 3:22-23. Kristus sendiri berbicara bahwa Dia adalah seorang Nabi (Luk.13:33). Dia membawa berita dari Bapa-Nya (Yoh.8:26-28), Dia menyatakan hal-hal yang berhubungan dengan akhir zaman (Mat.24:3-35), Dia berbicara dengan otoritas, berbuat mujisat, dan masih banyak yang lain.

${ }^{13}$ Markus 14:61-64 


\section{Kemesiasan Yesus Dalam Lukas 4:18-19}

Lukas banyak sekali menyebutkan Yesus sebagai Mesias atau Kristus, dan para pengikut Kristus disebut sebagai orang Kristen (band.Kis.11:26; 26:28). Yesus disebut sebagai Kristus ketika Dia lahir (2 :11,26). Ketika berkotbah di Nazareth, Yesus diurapi oleh Roh Tuhan yang menandakan bahwa Dia adalah Kristus (4:18) sekalipun Dia melarang untuk menyiarkan bahwa Dia adalah Mesias (4:41). Larangan ini tidak boleh ditafsirkan bahwa Dia bukan Mesias atau merahasiakan ke-mesiasan-Nya. Dalam Lukas 9:20, Petrus secara singkat mengatakan "Mesias dari Allah' untuk menjawab pertanyaan Tuhan Yesus: "menurut kamu siapakah Aku ini?

Leon Morris mengomentari bagian ini demikian: "The knowledge of Christ is always a personal discovery, not the passing on of report learnt from other people". 14

Sebagai Mesias, Orang yang diurapi, Yesus dalam pengajaran dan pelayanan-Nya, tidak hanya menekankan aspek religious internal, aspek religius ekternal tetapi juga aspek sosial-ekonomi yang menyangkut kekinian.

Lukas 4:18-19 merupakan salah satu bagian dalam Injil Lukas yang menunjuk kepada perhatian Yesus dalam ketiga aspek di atas. Dalam khotbahNya di Nazareth, Yesus mengajarkan bahwa apa yang dinubuatkan oleh Nabi Yesaya telah terwujud dalam diri-Nya. Orang yang diurapi dengan Roh Allah itu adalah Yesus sendiri. Kata-Nya: "Pada hari ini genaplah nats ini sewaktu kamu mendengarkannya" (4:21).

Tuhan Yesus memulai pelayanan-Nya sebagai orang yang diurapi oleh Roh Kudus atau Mesias. Semua karunia dan rahmat dari Roh diberikan kepada-Nya tanpa batas. Tidak seperti para nabi dalam Perjanjian Lama yang sangat terbatas. Yohanes 3:34 mengatakan: "sebab siapa yang diutus Allah, Dia-lah yang menyampaikan firman Allah, karena Allah mengaruniakan RohNya dengan tidak terbatas."

\footnotetext{
${ }^{14}$ David Imam Santoso, Theologi Lukas, Malang: Lteratur SAAT, 2006, 73
} 
Lalu, apa yang diperbuat-Nya sebagai seorang Mesias dalam Lukas 4:18-19?

\section{Dia menjadi seorang Nabi yang besar}

Dia diurapi atau ditugasi (ekrise) untuk menyampaikan kabar baik (euanggelisastai) kepada orang miskin. Kepada semua orang miskin (ptokhois) di dunia. Kata ptokhos artinya: sangat miskin; yang berharap pada Tuhan, yang tidak berguna.

Injil Lukas dikenal sebagai Injil untuk orang-orang miskin. Lukas memberikan tempat bagi orang miskin dalam karya keselamatan Yesus. Yesus memberi yang baik kepada yang lapar (1:53); Yesus membawa kabar baik bagi orang miskin (4:18); juga memberitakan Kerajaan Allah bagi orang miskin (6:20); memberi perhatian kepada Lazarus yang lapar dan miskin (6:19-31). Dia membawa kabar baik bagi orang miskin secara materi maupun secara rohani, orang yang sangat berharap kepada-Nya, orang yang dianggap tidak berguna bagi sesamanya. Dia juga berkhotbah untuk orang yang lemah dan rendah hati, orang-orang yang benar-benar sedih karena dosa. Kepada mereka Dia menyampaikan Injil yang mengubah hati mereka.

Pokok-pokok yang dikhotbahkan antara lain: a). Pembebasan/ pengampunan bagi tawanan (perang) (aikhmalotois apesin). Injil adalah proklamasi pembebasan; pembebasan dari hal yang terburuk; b). Pemulihan atau penglihatan bagi orang buta (tuplois anablepin). Dia datang tidak hanya membawa terang Injil bagi yang duduk dalam kegelapan, tetapi kekuatan kasih karunia-Nya memberi pandangan kepada mereka yang buta atau memberi pengertian kepada mereka yang tidak sanggup mengerti. c). Dia juga datang untuk memberitakan tahun rahmat Tuhan telah datang. Dia datang supaya dunia mengetahui bahwa Allah bersedia berdamai dengan mereka. Itulah tahun Yobel, tahun pembebasan, hari keselamatan.

\section{Dia datang sebagai seorang dokter yang hebat}

Dia dikirim untuk menyembuhkan manusia yang patah hati, memberikan ketenangan kepada mereka yang bermasalah, menyembuhkan luka hati, membawa mereka yang lelah untuk beristirahat, dan yang berbeban berat karena dosa supaya dilepaskan (bandingkan dengan Matius 11:28-30). 


\section{Dia datang menjadi seorang Penebus yang besar}

Dia tidak hanya menyatakan kebebasan bagi para tawanan tetapi memberi kebebasan kepada mereka (aposteilai tetrausmenous en apesei artinya: menyuruh pergi orang-orang yang ditindas dengan pembebasan) . Para Nabi hanya dapat memberitakan tetapi hanya Tuhan Yesus yang memberi kebebasan karena Dia-lah yang memiliki otoritas dan kekuasaan untuk mengampuni dosa.

\section{IMPLEMENTASI KEMESIASAN YESUS BERDASARKAN LUKAS 4:18-19 DALAM HOLISTIC MINISTRY GEREJA}

Meneladani Yesus sebagai Kepala Gereja, Gereja harus bisa mengembangkan pelayanan yang bersifat holistic yang mencakup semua aspek kebutuhan manusia, yang merupakan perpaduan antara pelayanan rohani dan pelayanan sosial/yang bersifat jasmaniah. Itulah yang dilakukan Yesus sebagai Mesias. Walaupun tidak mudah tetapi harus diusahakan karena untuk itulah Gereja dihadirkan di dunia ini. Dunia tempat gereja berada sedang mengalami krisis multidimensi. Krisis yang satu belum sempat diatasi, muncul krisis yang lain, dan dampaknya sangat dirasakan oleh masyarakat termasuk orang Kristen. Misalnya Krisis ekonomi dan masalah kemiskinan. Jumlah orang miskin dari tahun ke tahun bertambah di seluruh dunia termasuk di Indonesia. Kemiskinan terjadi di semua bidang. Tidak hanya miskin secara materi tetapi juga miskin pendidikan, miskin kesehatan, miskin kebebeasan dan lain-lain. ${ }^{15}$

Menurut Nababan, kemiskinan ini bisa disebabkan karena keterbelakangan, kurangnya pendidikan, sistem, struktur dan peraturan warisan kolonialisme dan feodalisme dalam masyarakat lokal, nasional, universal yang tidak mencerminkan keadilan, bahkan cenderung terus mendukung yang kaya makin kaya dan miskin makin miskin, dan terus melindungi aneka ragam eksploitasi terutama dalam era globalisasi yang dikuasai oleh korporatokrasi ini. Pemahaman agama yang tidak menyeluruh, dan penyampaian ajaran agama yang cenderung tekstual dan tidak kontekstual ikut memperlambat usaha

\footnotetext{
15 Soritua A E Nababan, Misi Gereja dan Pemulihan Bangsa dalam Holictic Global Mission, Batu: Departemen Multi Media, 2007, h.306
} 
mengatasi atau mengentaskan kemiskinan. ${ }^{16}$ Selain masalah kemiskinan, masih banyak pekerjaan rumah gereja antara lain: masalah perceraian, bunuh diri, seks bebas, tawuran remaja, narkoba yang tidak dapat dibendung lagi dan masalah degradasi lingkungan hidup yang semakin parah.

Hasil analisa tersebut di atas kiranya menjadi perhatian gereja yang serius. Gereja harus berdoa supaya Tuhan memulihkan keadaan di atas. Itu baik. Tetapi itu belum cukup. Selain berdoa, Gereja harus memikirkan tindakan-tindakan nyata-praktis sebagai upaya partisipasi dalam masyarakat. Gereja tidak boleh hanya hidup untuk diri sendiri tetapi gereja harus berusaha memperhatikan dinamika kehidupan dalam masyarakat di sekitarnya. Gereja harus melibatkan anggotanya untuk ikut aktif menyelesaikan persoalan masyarakat di sekitarnya. Program-program gereja, baik jangka pendek maupun jangka panjang, hendaknya tidak hanya berorientasi untuk kebutuhan rohani jemaat, tetapi juga berorientasi kepada kebutuhan masyarakat di sekitarnya baik secara rohani, secara moral, secara sosial, secara psikologis, dsbnya.

Masalahnya, belum semua gereja di dunia atau secara khusus di Indonesia menyadari pentingnya mengembangkan holistic ministry (aspek religious internal, aspek religius eksternal dan aspek sosial-ekonomi kekinian). Bisa jadi karena ada gereja-gereja, baik pribadi, persekutuan atau secara lembaga masih terjebak dalam pola pikir dikotomik yang membagi realita di masyarakat dalam dua kategori yang berbeda. Yang satu berhubungan dengan dunia rohani (penginjilan, khotbah, doa, kebaktian, PA), yang sering dianggap lebih tinggi nilainya dari yang berhubungan dengan hal-hal yang bersifat jasmani (pelayanan sosial). Cara pandang seperti ini jelas mempengaruhi pola pikir, cara pandang dan tindakan sehari-hari. Akibatnya, gereja cenderung mengutamakan hal-hal yang rohani dan menjauhi hal-hal yang bersifat jasmani.

Untuk hal-hal yang bersifat jasmani dan sosial, gereja menganggap sudah cukup dengan mendoakannya.

Bambang Wijaya mengatakan: Injil yang otentik harus nampak terlihat dalam transformasi kehidupan manusia. Sementara gereja memberitakan kasih

${ }^{16}$ Ibid, h.308 
Tuhan Yesus, gereja harus terlibat dalam pelayanan kasih. Sementara Gereja mengkhotbahkan Kerajaan Allah, gereja harus berkomitmen kepada keadilan dan damai. ${ }^{17}$

Penginjilan adalah tugas utama Gereja supaya semua orang memiliki kesempatan menerima Tuhan Yesus sebagai Tuhan dan Juruselamat. Itulah mandat yang telah diberikan Tuhan Yesus (Mat.28:18-20). Dalam PelayananNya di dunia, Tuhan Yesus dengan kuasa, memberitakan dan mengajar banyak orang tentang Injil kasih karunia, tetapi sebagai Mesias, Dia juga dengan semangat dan kuasa yang sama, memperhatikan orang miskin, Dia memberi makan mereka yang lapar, melayani orang sakit, merawat orang tawanan, menolong mereka yang cacat dan membebaskan yang tertindas. Dengan kalimat lain: Dalam diri Tuhan Yesus: Kabar Baik dan perbuatan baik tidak terpisahkan. Baik hal rohani dan hal jasmani tidak dipisahkan. Inilah yang dikatakan sebagai bentuk Holictic Ministry Sang Mesias. Demikian seharusnya gereja di tengah-tengah masyarakat.

Bagaimana gereja secara praktis menjawab tantangan ini ?

Dan Raja itu akan menjawab mereka :

"Aku berkata kepadamu, sesungguhnya segala sesuatu yang kamu lakukan untuk salah seorang dari Saudara-Ku yang paling hina ini, kamu telah melakukannya untuk Aku"

(Matius 25:40)

${ }^{17}$ Bambang H Wijaya, Pelayanan Misi Holistic Di Dalam Masyarakat Majemuk, Batu: Departemen Multi Media, 2007, h.318 


\section{DAFTAR PUSTAKA}

Boeker, TGR

1991 Apa Kata Alkitab Tentang Roh Kudus, Batu: I-3

Nababan, Soritua AE

1007 Misi Gereja dan Pemulihan Bangsa dalam Holictic Global Mission, Batu: Departemen Multi Media

Santoso, David Imam

2006 Theologi Lukas, Malang: Literatur SAAT

Siahaan, S.M.

1991 Pengharapan Mesias Dalam Perjanjian Lama, Jakarta: BPK Gunung Mulia

Wijaya, Bambang $\mathrm{H}$.

2007 Pelayanan Misi Holistic Di Dalam Masyarakat Majemuk, Batu:

Departemen Multi Media 